Health Promotion:

Professional Perspectives 


\section{Health Promotion}

\section{Professional Perspectives}

Edited by

Angela Scriven

and

Judy Orme

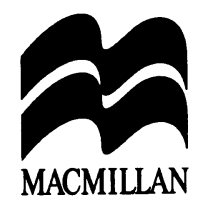


Selection and editorial matter (C) Angela Scriven and Judy Orme 1996

Individual chapters (in order) (C) Keith Tones, Faith Delaney, Lee Adams, Penny Astrop and Jonathan McWilliam, Judy Orme and Cheryl Wright, Linda Ewles, Sue Latter, Peter Allen, Linda Jones and Jon Bloomfield, Robin Ireland, Angela Scriven, Alan Beattie, Stephen Farrow, Miriam Jackson, Ann Payne, Yvonne Anderson and Zoë Heritage, Jan Myers and Kate Marsden, Diana Sanders and Sally Crowe, Miriam Glover, Marc Beishon and Sarah Veale, Jennifer Lisle 1996

All rights reserved. No reproduction, copy or transmission of this publication may be made without written permission.

No paragraph of this publication may be reproduced, copied or transmitted save with written permission or in accordance with the provisions of the Copyright, Designs and Patents Act 1988, or under the terms of any licence permitting limited copying issued by the Copyright Licensing Agency, 90 Tottenham Court Road, London W1P 9HE.

Any person who does any unauthorised act in relation to this publication may be liable to criminal prosecution and civil claims for damages.

First published 1996 by

MACMILLAN PRESS LTD

Houndmills, Basingstoke, Hampshire RG21 6XS

and London

Companies and representatives

throughout the world

ISBN 978-0-333-64497-3 ISBN 978-1-349-24580-2 (eBook)

DOI $10.1007 / 978-1-349-24580-2$

A catalogue record for this book is available from the British Library

$\begin{array}{llllll}10 & 9 & 8 & 7 & 6 & 5\end{array}$

$\begin{array}{llllll}05 & 04 & 03 & 02 & 01 & 00\end{array}$ 


\section{Contents}

List of figures and tables viii

The contributors $\quad$ ix

Acknowledgements $\quad$ xiv

Introduction

Angela Scriven and fudy Orme 1

Section One: Issues concerned with theory and practice

1 The anatomy and ideology of health promotion: empowerment in context

Keith Tones

2 Theoretical issues in intersectoral collaboration Faith Delaney

\section{Section Two: Health service}

3 The role of health authorities in the promotion of health Lee Adams

4 The role of the Family Health Service Authorities in promoting health

Penny Astrop and fonathan McWilliam

5 Health promotion in primary health care fudy Orme and Cheryl Wright

6 The impact of the NHS reforms on specialist health promotion in the NHS

Linda Ewles

7 The potential for health promotion in hospital nursing practice

Sue Latter 


\section{vi Contents}

\section{Section three: Local authority}

8 Health promotion, environmental health and the local authority Peter Allen

9 Promoting health through social services Linda fones and fon Bloomfield

10 Health promotion through leisure services Robin Ireland.

\section{Section Four: Education and youth organisations}

11 The impact of recent government policy on the provision of health education in schools Angela Scriven

12 The health promoting school: from idea to action Alan Beattie

13 The role of the school nurse in promoting health Stephen Farrow

14 Health promotion in a youth work setting Miriam fackson

15 Health promotion in further education Ann Payne

\section{Section Five: Voluntary}

16 The voluntary setting and its contribution to health promotion Yvonne Anderson and Zoë Heritage

17 A self-help approach to health promotion fan Myers and Kate Marsden

\section{Section Six: Workplace}

18 Overview of health promotion in the workplace Diana Sanders and Sally Crowe

19 Alliances for health at work: a case study Miriam Glover 
Contents vii

20 Trade unions and health promotion Marc Beishon and Sarah Veale

21 The role of occupational health services in promoting health Jennifer Lisle

Author index

239

Subject index

245 


\section{List of figures and tables}

\section{Figures}

1.1 Health education, empowerment and health promotion 14

1.2 Empowerment: the education process 15

8.1 Partners in the 'Airwatch Partnership Project' 92

10.1 Sports development model 108

12.1 Beattie's matrix of health promotion strategies 139

15.1 The health promoting college - framework for
development

\section{Tables}

12.1 Aims of the European network of health promoting schools

12.2 Criteria for a health promoting school 131

12.3 Key areas for action to create a healthy school

12.4 The Tannahill framework applied to developing the health promoting school

12.5 The Ryder and Campbell 'PERM' framework for developing PSHE

12.6 Ryder and Campbell's model of 'healthy organisational life' in schools

12.7 The Ewles and Simnett framework and the school as a healthy workplace

12.8 The Beattie matrix as a planning grid for the health promoting school

20.1 Union density by type of occupation (1991)

20.2 Union density by size of workplace (1991) 


\section{The contributors}

Lee Adams is Director of Health Promotion for Sheffield Health Authorities, and a member of the Healthy Sheffield Board. Her career spans 20 years, and includes being chair of the Society of Health Education/Promotion Specialists, a Director at the Health Education Authority and membership of the National Executive of the Family Planning Association. She is author of numerous publications.

Peter Allen is Head of Environmental Health at Oxford City Council and a Member of Green College, Oxford. He has written and lectured extensively on health promotion in local government.

Yvonne Anderson is a freelance education and training consultant. Yvonne became freelance in 1990 after a career in teaching, lecturing and residential care work. She works with a variety of voluntary organisations, including Victim Support Wiltshire, and she also serves on a voluntary organisation's management committee.

Penny Astrop is an experienced health service manager, currently working with Oxfordshire Family Health Service Authority (FHSA). Penny previously worked as a health visitor, health promoter and primary care team development facilitator. She specialises in the management of change, multiprofessional and interagency working.

Alan Beattie's career as a practitioner and researcher in health promotion spans 20 years in the NHS, school and voluntary settings, as well as universities. Alan was involved in the development of health promotion courses and research projects at London University from 1977 to 1989. He has been Honorary Senior Research Fellow in Applied Social Science at the Centre for Health Research at Lancaster University since 1989, becoming Head of Health Studies and Human Sciences at St Martin's College, Lancaster, in 1993, where he is now Professor in Health Promotion.

Marc Beishon is a freelance editor and writer. He has written regularly for Healthlines, the Health Education Authority's health promotion magazine, on a wide range of 'the health of the nation' topics. He has also carried out assignments on the information technology and publishing industries, as well as the education sector. Previously, he was managing editor of New Scientist magazine. 
Jon Bloomfield, an economic and social historian by training with a $\mathrm{PhD}$ in post-war Czechoslovak history, has worked in local government in Coventry and Birmingham for the last decade. He is currently responsible for editing Birmingham's Community Care and Child Services plans and he coordinates the local authority's relations with all parts of the city's health services.

Sally Crowe is a Senior Health Promotion Specialist at South Buckinghamshire Health Promotion Service. After ten years' nursing experience and a spell in adult education, she moved into health promotion in 1991, specialising in workplace health issues. She currently works in sexual health, but maintains an interest in the development of workplace health promotion programmes.

Faith Delaney is a Senior Lecturer at Leeds Metropolitan University. She previously worked in local government and in the health service, as a nurse, researcher and health promotion specialist. She has experience of teaching and training with a wide range of occupational groups. She has published on intersectoral collaboration, health promotion in nursing and inequalities in child health. Research interests include public health strategy, evaluation and health promotion theory.

Linda Ewles is Health Promotion Manager for Avon Health Commission. She has worked as a health promotion specialist for over 20 years, in the NHS and in higher education. She is the author of many published articles, but most notably, with Ina Simnett, of Promoting Health - A Practical Guide, now in its third edition.

Stephen Farrow is Public Health Professor at Middlesex University and a Director of Public Health in Barnet. Previous posts include director of a university institute which specialised in the evaluation of health care. He has worked extensively on a range of projects and has acted as a consultant for the World Health Organisation, as well as many other national and international organisations.

Miriam Glover has worked in health promotion since 1989, specialising in the workplace setting. She has worked for Somerset Health Authority, the Health Education Authority and South West Regional Health Authority. Miriam is currently Health Promotion Alliances Manager in Somerset.

Zoë Heritage is a freelance consultant and trainer. After working in Africa for a number of voluntary organisations, she joined the Health Education Authority's (HEA's) Primary Health Care Unit as the 
Community Development Officer. She is now a freelance consultant and she sits on the management committees of several voluntary organisations. In 1994 she edited the Royal College of GP's publication Community Participation in Primary Care.

Robin Ireland set up his own consultancy in 1993 specialising in lifestyle events, research and training. He has spent more than 10 years in the leisure and health promotion industries and has a keen personal interest in physical activity.

Miriam Jackson is currently a Senior Youth Work Development Adviser with the National Youth Agency. She previously worked for the Council for Education and Training in Youth and Community Work as an adviser and as a youth worker in three different local education authorities' youth services. Her published work includes two videos-led training packs, Building Portfolios 1 and 2, A Personal Training Adviser's Handbook and Holistic Approaches to Health Education in Youth Work.

Linda Jones is Lecturer in Health and Wellbeing and Chair of the Health Programme Area in the School of Health and Social Welfare at the Open University. Her research interests focus on the early growth of statutory welfare services and contemporary health policy. Her recent publications include The Social Context of Health and Health Work (1994) and (as co-editor) Health and Wellbeing: A Reader (1993).

Sue Latter is Principal Lecturer in Health Promotion at the Nightingale Institute, London. She has worked as a nurse in both hospital and community settings. Her research interests and publications have focused on nurses' perceptions and practice of health promotion in hospital settings.

Jennifer Lisle is a physician with a professional background in public health, psychological medicine and occupational health. As Director of Joint Research and Health Advisers since 1985 she has worked with both public and private sector organisations on a wide range of workplace health issues, including employee mental health and the design of occupational health services. She is a Senior Visiting Fellow at City University..

Kate Marsden is the Consumer Relations Officer at University Hospital Queens Medical Centre NHS Trust. Until recently she was the Information Officer at the Nottingham Self-Help Team. She was a contributing editor to Self-Help: An Annotated Bibliography 19831993 and various articles on self-help and information. 
Jonathan McWilliam is a Consultant in Public Health Medicine and Director of Health Strategy with Oxfordshire FHSA. His main interests include developing the role of GPs and purchasers and unifying the policies of DHAs and FHSAs, including health promotion policy.

Jan Myers is Training and Development Working/Assistant Team Leader at the Nottingham Self-Help Team. She is a qualified social worker and has worked in the voluntary sector for about 15 years. She has contributed to Team publications and various articles for sector magazines.

Judy Orme is a Senior Lecturer in Health Promotion at the University of the West of England in Bristol. Her background is in healthrelated research at the University of Bristol. Current research interests are health promotion in general practice, women's health and physical activity patterns in young people.

Ann Payne is currently a member of Tailor Made Training, Director of the HEA Health Promoting College project, and Coordinator for the Health Promotion Wales (HPW) Healthy Colleges' project. Her background includes social work, nursing, teaching in further education and research. Publications include Training on the Right Track (1991).

Diana Sanders is a Chartered Counselling Psychologist, working in the Oxfordshire Mental Health Care NHS Trust and Oxford University. She has a background in health promotion and research and has published on health promotion in the workplace, smoking cessation, health promotion in primary care and women's health.

Angela Scriven is Course Director for the MSc in Health Promotion and Subject Leader for Health Studies and Health Education in the undergraduate modular degrees at Bath College of Higher Education. Research interests and publications are centred on health education in schools and, more recently, women's health.

Keith Tones is Professor of Health Education at Leeds Metropolitan University. He has been involved in postgraduate health education teaching for over 20 years, and has acted as a consultant for the World Health Organisation and many other international and national organisations. He has published extensively.

Sarah Veale is a Senior Policy Officer at the Trades Union Congress. Her main responsibilities are for individual employment rights and workplace health promotion. She is a member of the Govern- 
ment's 'The Health of the Nation' Workplace Steering Group. She has spoken extensively on the role of trade unions in workplace health promotion.

Cheryl Wright has 11 years' health visiting experience and is now a Senior Nurse Manager in Gwent. During 1993 and 1994 she carried out extensive research into adolescent health, collaborating closely with major purchasers and providers of primary health care services in Bath. 


\section{Acknowledgements}

Special thanks to Sue Nancholas and Caroline Rubery for their assistance in compiling the original proposal for the book and to Tina Jolly for her diligence and patience in finalising the manuscript. 